\section{Occurrence of cassava mealybug, Phenacoccus manihoti Matile-Ferrero (Pseudococcidae: Hemiptera), a new invasive pest on cassava in India and prospects for its classical biological control}

M. Sampathkumar ${ }^{1}$, M. Mohan ${ }^{1, *}$, A. N. Shylesha ${ }^{1}$, Sunil Joshi ${ }^{1}$, T. Venkatesan ${ }^{1}$, Ankita Gupta ${ }^{1}$, S. Vennila ${ }^{2}$, S. R. Venkatachalam ${ }^{3}$, M. Vijayakumar ${ }^{4}$, Madhu Subramanian $^{5}$, M. Yoganayagi, T. R. Ashika ${ }^{1}$ and N. Bakthavatsalam ${ }^{1}$

${ }^{1}$ ICAR-National Bureau of Agricultural Insect Resources, Hebbal, Bengaluru 560 024, India

${ }^{2}$ ICAR-National Centre for Integrated Pest Management, New Delhi 110 102, India

${ }^{3}$ Tapioca and Castor Research Station, Tamil Nadu Agricultural University, Yethapur 636 119, India

${ }^{4}$ Krishi Vigyan Kendra, Sandhiyur 636 204, India

${ }^{5}$ Directorate of Research, Kerala Agricultural University, Thrissur 680 656, India

${ }^{6}$ State Department of Horticulture and Plantation Crops, Tamil Nadu, Senthamangalam 637 409, India

Increased globalization and trade have made India a target for entry of many new alien insect pests. One such unintentional recent introduction is the cassava mealybug (CMB), Phenacoccus manihoti on cassava. Monitoring on the occurrence and damage potential of CMB on cassava was undertaken during 2020. Among the places surveyed, maximum damage score (4-5) and density of the mealybug $(>1000 /$ shoot tip) were recorded in Salem and Namakkal districts of Tamil Nadu and Thrissur district of Kerala. In the absence of effective native natural enemies and other methods of control, $\mathrm{CMB}$ might pose a major crisis to the cassava industry in India. The prospects of its suppression by classical biological control are quite vibrant and the initiative to import the parasitoid wasp, Anagyrus lopezi from Thailand and the Republic of Benin is already being taken by ICAR-NBAIR, Bengaluru, India.

Keywords: Biological control, damage, invasive, monitoring, Phenacoccus manihoti.

CASsAvA, also called tapioca (Manihot esculenta Crantz), is an important industrial crop native to North-East Brazil. India occupies fifth place in world's cassava cultivation, and exports around 3563 tonnes of value-added cassava byproducts and flour to nearly 18 countries with an export revenue generation of Rs 200 million for 2019 20 (http://agriexchange.apeda.gov.in/). Cassava crop is cultivated predominantly in the southern states of which

\footnotetext{
*For correspondence. (e-mail: Mohan.M@icar.gov.in)
}

Tamil Nadu and Kerala are responsible for $51.9 \%$ and $31.7 \%$ of area and $57.8 \%$ and $34.9 \%$ of production respectively ${ }^{1}$. It is also grown in Andhra Pradesh, Karnataka, Madhya Pradesh, North Eastern States and to some extent in Pondicherry and Andaman and Nicobar group of Islands.

Cassava was relatively free of any serious pest till the accidental introduction of papaya mealybug (PMB), Paracoccus marginatus Williams \& Granara de Willink (Hemiptera: Pseudococcidae) in 2008 (ref. 2). Papaya mealybug might have been introduced into India from Sri Lanka $^{3}$. Since the introduced pests are always amenable to classical biological control, the encyrtid parasitoids Acerophagus papayae Noyes \& Schauff, Anagyrus loecki Noyes and Menezes and Pseudleptomastix mexicana Noyes \& Schauff were imported from Puerto Rico through USDAAPHIS by ICAR-NBAIR, Bengaluru and introduced in India during 2010 (ref. 4). A. papayae established very well under field conditions and continues to suppress the $P$. marginatus populations on many crops 5 .

The recent most serious biological invasion is the cassava mealybug (CMB), Phenacoccus manihoti MatileFerrero (Hemipera: Pseudococcidae) on cassava. In India, occurrence of this pest was first noticed on cassava in Thrissur, Kerala during April 2020. Identity of the mealybug samples was established by ICAR-NBAIR ${ }^{6}$. The CMBs are pinkish in colour and covered with mealy coating, and usually infest the shoot tips and under surface of the leaves. All the stages of mealybug, viz. eggs, nymphs and adults (Figure 1) were observed on the plant parts

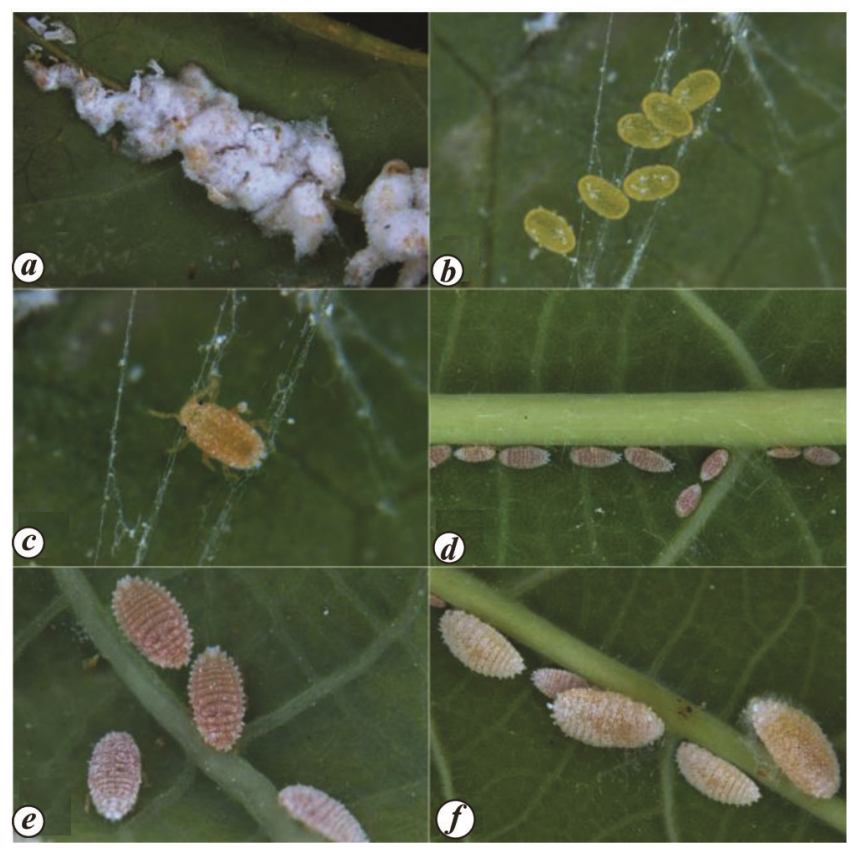

Figure 1. Life stages of Phenacoccus manihoti Matile-Ferrero. a, Ovisacs; $\boldsymbol{b}$, Eggs; $\boldsymbol{c}$, First instar (crawler); $\boldsymbol{d}$, Second instar females beginning infestation around leaf veins; $\boldsymbol{e}$, Third instar females exhibiting typical pink colour of the species; $\boldsymbol{f}$, Grown up females turning yellow and initiating oviposition. 


\section{RESEARCH COMMUNICATIONS}

Table 1. Survey on the occurrence and damage potential of cassava mealybug (CMB) on cassava crop in the cassava growing states

\begin{tabular}{|c|c|c|c|c|c|}
\hline District (Block) & Village name & $\begin{array}{l}\% \text { infested } \\
\text { plants }\end{array}$ & $\begin{array}{l}\% \text { plants with } \\
\text { bunchy top }\end{array}$ & $\begin{array}{c}\text { P. manihoti } \\
\text { density scale* }\end{array}$ & $\begin{array}{l}\text { Shoot tip } \\
\text { damage scale }{ }^{* *}\end{array}$ \\
\hline \multicolumn{6}{|l|}{ Tamil Nadu } \\
\hline Salem (Edappadi) & Vellarivelli & $26.5-73.4$ & $14.3-56.2$ & 4 & $4-5$ \\
\hline Salem (Pethanaickanpalayam) & Ethapur & $21.2-36.5$ & $22.5-29.6$ & 4 & $3-4$ \\
\hline Namakkal (Vennandur) & Mallur & $19.0-28.2$ & $1.8-13.2$ & 3 & $3-4$ \\
\hline Namakkal (Rasipuram) & Murungapatti, Bodinayakkanpatti & $7.0-33.6$ & $2.2-23.5$ & 2 & $2-3$ \\
\hline Namakkal (Namagiripettai) & $\begin{array}{l}\text { Oduvankurichi, Ariyagoundampatti, } \\
\text { Thoppapatti, Tho. } \\
\text { Pachudaiampalayam, } \\
\text { T. Jedarpalayam, Kullandikadu }\end{array}$ & $9.2-86.7$ & $1.2-74.3$ & 4 & 5 \\
\hline Namakkal (Senthamangalam) & $\begin{array}{l}\text { Kalkurichi, Rootupudur, Vellalapatti, } \\
\text { Valayapatti, Pallipatti, Eachampatti }\end{array}$ & $36.4-81.3$ & $13.1-72.4$ & 4 & 5 \\
\hline Erode (Modakurichi) & Avalpoondurai & $8.5-11.0$ & 0.0 & 1 & 2 \\
\hline Dharmapuri (Palacode) & Agaram & 0.0 & 0.0 & 1 & 1 \\
\hline Dharmapuri (Morappur) & Annamalai Halli, Kellavalli & 0.0 & 0.0 & 0 & 1 \\
\hline Dharmapuri (Pappireddipatti) & Avarangkattur, & 0.0 & 0.0 & 0 & 1 \\
\hline \multicolumn{6}{|l|}{ Kerala } \\
\hline Thrissur & $\begin{array}{l}\text { Kannara, Punnamparambu, } \\
\text { Mukkattukkara, Cathankkulam, } \\
\text { Meppadam, Talikkode, } \\
\text { Thannikkudam, Peruvallur, } \\
\text { Vellanikkara, Kachithode }\end{array}$ & $6.7-46.7$ & $2.3-39.8$ & 3 & $2-4$ \\
\hline \multicolumn{6}{|l|}{ Karnataka } \\
\hline $\begin{array}{l}\text { Dakshina Kannada, } \\
\text { Chikmagaluru, Udupi, } \\
\text { Mysore, Hassan, Madikeri, } \\
\text { Chamarajanagar }\end{array}$ & - & Nil & Nil & Nil & Nil \\
\hline \multicolumn{6}{|l|}{ Andhra Pradesh } \\
\hline East Godavari & $\begin{array}{l}\text { Peddapuram, Jaggampeta and } \\
\text { Rangampeta Mandals }\end{array}$ & Nil & Nil & Nil & Nil \\
\hline
\end{tabular}

causing curling of the leaves at growing tip of the plant leading to formation of bunchy tops and adventitious buds on almost all the internodes. Heavy population resulted in drying of the leaves and complete defoliation. Initially it was presumed that the invasion by $P$. manihoti was restricted to a small area in Kerala until the present survey was undertaken in cassava growing districts of Tamil Nadu. The cassava plants in Edappadi (Salem district), Namagiripettai and Senthamangalam (Namakkal district) blocks were found severely damaged by $P$. manihoti (https://www.nbair.res.in/sites/default/files/2020-06/ Cassava_mealybug monitoring.pdf). It is soon expected to spread to other cassava growing areas of the country.

In the present study, morphological identification of the samples was further compared to the DNA based identification. All the life stages of mealybug collected from the field were subjected for DNA extraction as per OEPP/EPPO guidelines ${ }^{7}$ with essential modifications according to Pacheco da Silva et al. ${ }^{8}$.

The extracted DNA was used for polymerase chain reaction (PCR) amplification of partial mitochondrial cytochrome c oxidase 1 (CO1) gene using the forward (LCO 1490 5'-GGTCAACAAATCATAAAGATATTGG$\left.3^{\prime}\right)$ and reverse primer (HCO 2198 5'-TAAACTTCAGGGTGACCAAAAAATCA-3') as per the standard protocol $^{9}$. The sequences (NCBI accession numbers MT895817 and MW039322) showed 100\% identity with GenBank accession numbers of $P$. manihoti, KY611349, KY611348, KY611347 and KY611346 submitted from China.

Sampling for the occurrence of mealybug and its natural enemies was done in unsprayed cassava crop in farmers' fields. The number of plants showing bunchy top symptoms was estimated by counting the total plants and plants with bunchy top in a fixed area of 100 sq. $m$ at different fields. Twenty-five randomly collected shoot tips from the infested plants were used for assessing the CMB population density.

The average number of $P$. manihoti per shoot tip was assigned to one of the following categories as per Neuenschwander et al. ${ }^{10}$ as 0, 1-9, 10-99, 100-999 and $\geq 1000$. The $\log (X=1)$ transformed upper values of mealybugs under these categories were assumed as $0,1,2,3$ and 4 respectively. The same shoot tip samples were used for scoring the damage scale as described by Nwanze ${ }^{11}$ and Pronam ${ }^{12}$ as 1 , no damage; 2 , slight curling of leaf margins; 3, slight bunching of the tip; 4, pronounced distortion of the tip (bunchy top); 5 , severe defoliation.

Cassava varieties namely, Mulluvadi, white Thailand, Sree Athulya and Sree Vijaya cultivated during 2020 at 

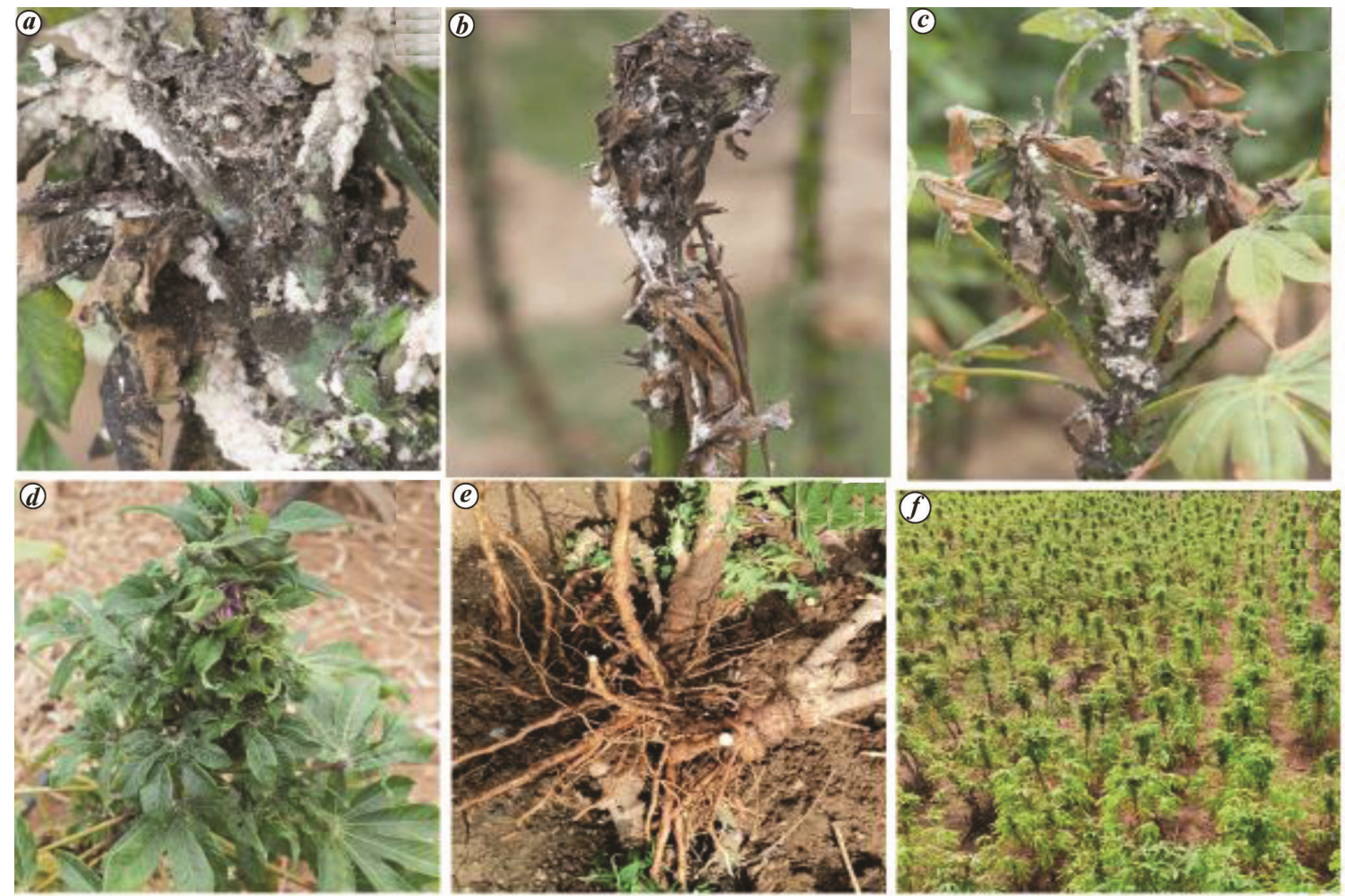

Figure 2. Symptoms on cassava due to cassava mealybug damage. $\boldsymbol{a}$, Severely infested twig; $\boldsymbol{b}$, Dried twig; $\boldsymbol{c}$, Drying of leaves and shoot tip; $\boldsymbol{d}$, Cassava plant with bunchy top appearance; $\boldsymbol{e}$, Cassava plant with no tuber formation; $\boldsymbol{f}$, Stunted cassava plants in the field.

Table 2. Severe reduction of harvest index due to CMB infestation in ruling varieties of cassava at the study sites (Senthamangalam and Namagiripettai blocks of Namakkal district in Tamil Nadu)

\begin{tabular}{lcc}
\hline & \multicolumn{2}{c}{ Harvest index } \\
\cline { 2 - 3 } Cassava variety & CMB infested fields & Uninfested fields \\
\hline Mulluvadi & 0.06 & 0.68 \\
& 0.03 & 0.47 \\
White Thailand & 0.02 & - \\
& 0.06 & - \\
& 0.04 & 0.61 \\
Sree Athulya & 0.03 & 0.58 \\
& 0.06 & - \\
Sree Vijaya & 0.00 & - \\
& 0.00 & 0.63 \\
& 0.09 & - \\
& 0.24 & 0.57 \\
& 0.12 & 0.60 \\
\hline
\end{tabular}

Edappadi and Pethanaickenpalayam blocks of Salem district and Rasipuram, Senthamangalam and Namagiripettai blocks of Namakkal district of Tamil Nadu were severely infested with CMB. The setts of the above varieties planted between November 2019 and January 2020 were found severely infested during the dry summer months (March-June 2020) (Table 1). The pinkish oval mealybugs were commonly noticed on tender shoots, and at the under surface of the top leaves. Due to extreme sucking of plant sap by the mealybug, symptoms such as drying of leaves, distortion of stem, clumping of leaves, shortening of internodes and bunchy top were observed in highly infested and unsprayed fields (Figure 2). The per cent infested plants in the sampled villages varied from 7.0 to 86.7 , whereas the bunchy top symptoms appeared on up to $74.3 \%$ of the infested plants in certain locations especially in Edappadi, Senthamangalam and Namagiripettai blocks of Salem and Namakkal districts. The CMB density collected from these locations reached a maximum scale of 4 (equivalent to $\geq 1000$ mealybugs/shoot tip) with corresponding damage scales of 4 and 5, where, severe distortion and drying of shoot tip, stunting of the plant, defoliation and multiple tillering (bunchy top) occurred. Plants infested by $P$. manihoti were not only stunted, but also had lower harvest indices due to rudimentary or no tuber formation. The harvest index (HI) was estimated for the aforementioned four varieties at the time of harvest in different cassava fields at Namagiripettai and Senthamangalam blocks. The extremely infested Mulluvadi variety registered HI between 0.02 and 0.06 as against 0.47 and 0.68 under protected fields. In White Thailand variety, HI declined between 0.0 and 0.06 as against 0.58 and 0.61 under protected/uninfested condition. The cultivars Sree Athulya and Sree Vijaya registered decline in HI between 0.0 and 0.24 and 0.12 and 0.30 as against 0.58 and 0.63 and 0.57 and 0.60 of their respective protected/uninfested counterparts (Table 2). 


\section{RESEARCH COMMUNICATIONS}

The PMB, P. marginatus occurred during the initial stage of the crop was successfully controlled by the exotic parasitoid, A. papayae, whereas $P$. manihoti was not preferred by $A$. papayae. The absence of effective native natural enemies and the drought like situation have caused the CMB population to flare up. Though a fair population of Spalgis epeus ${ }^{6}$ Westwood (Lepidoptera: Lycaenidae) and predatory coccinellid beetle, Hyperaspis maindroni Sicard (Coleoptera: Coccinellidae) was found feeding on $\mathrm{CMB}$ in the unsprayed fields, the biocontrol potential of $H$. maindroni was severely hampered due to parasitization by a parasitoid, Homalotylus turkmenicus Myartseva (Hymenoptera: Encyrtidae) ${ }^{13}$.

Anagyrus lopezi (De Santis) (Hymenoptera: Encyrtidae), a parasitoid native to Central America, is being successfully used for the management of CMB in African and other Asian countries. A. lopezi is host-specific, and environmentally-adaptable ${ }^{14}$ and its parasitism levels were $10-57 \%$ in the mealybug affected fields in the released countries ${ }^{15}$. Host specificity studies conducted in other countries indicated that $A$. lopezi could develop only on $\mathrm{CMB}^{16}$. A large-scale biological control campaign by International Institute of Tropical Agriculture (IITA), Nigeria, in collaboration with numerous national and international organizations has led to the successful control of $P$. manihoti through the introduction and establishment of $A$. lopezi. Presently the parasitoid wasp has been established in 26 African and four Asian countries, imparting a substantial reduction in the population density of CMB in most farmers' fields ${ }^{17}$.

The introduction and release of the exotic parasitoid $A$. papayae by ICAR-NBAIR for the management of $P$. marginatus on cassava, mulberry and papaya was highly successful and reduced the pest incidence from $49 \%$ to $3 \%$ over a period of two years (2010-2012), and an annual saving of 1623 crores was accrued to the farmers in Tamil Nadu, Karnataka and Maharashtra (https://www. nbair.res.in/sites/default/files/2018-12/PMB\%20Brochure. pdf). ICAR-NBAIR has obtained import permit for importing A. lopezi from Thailand and Republic of Benin. The experience gained by ICAR-NBAIR will be used aptly for the management of the new invasive CMB by successful introduction of this exotic parasitoid after necessary quarantine studies at NBAIR QC-2 facility.

1. Anon., Horticulture Statistics at a Glance, Ministry of Agriculture and Farmers Welfare, Govt of India, 2018.

2. Muniappan, R., Shepard, B. M., Watson, G. W., Carner, G. R., Sartiami, D., Rauf, A. and Hammig, M. D., First report of the papaya mealybug, Paracoccus marginatus (Hemiptera: Pseudococcidae), in Indonesia and India. J. Agric. Urban Entomol., 2008, 25, 37-40.

3. Suresh, S., Jothimani, R., Sivasubrmanian, P., Karuppuchamy, P., Samiyappan, R. and Jonathan, E. I., Invasive mealybugs of Tamil Nadu and their management. Karnataka J. Agric. Sci., 2010, 23, 6-9.

4. Mani, M., Krishnamoorthy, A. and Shivaraju, C., Biological suppression of major mealybug species on horticultural crops in India. J. Hortic. Sci., 2011, 6, 85-100.
5. Shylesha, A. N., Joshi, S., Rabindra, R. J. and Bhumannavar, B. S., Classical biological control of the papaya mealybug. In Proceedings of the National Consultation Meeting on Strategies for Deployment and Impact of the Imported Parasitoids of Papaya Mealybug, PDBC, Bangalore, 2010.

6. Joshi, S., Pai, S. G., Deepthy, K. B., Ballal, C. R. and Watson, G., The cassava mealybug, Phenacoccus manihoti Matile-Ferrero (Hemiptera: Coccomorpha: Pseudococcidae) arrives in India. Zootaxa, 2020, 4772(1), 191-194.

7. PM7/129(1) DNA barcoding as an identification tool for a number of regulated pests. OEPP/EPPO Bull., 2016, 46(3), 501-537.

8. Pacheco da Silva, V. C., Bertin, A., Blin, A., Germain, J. F., Bernardi, D. and Rignol, G., Molecular and morphological identification of mealybug species (Hemiptera: Pseudococcidae) in Brazilian Vineyards. PLoS ONE, 2014, 9(7), e103267.

9. Hebert, P. D. N., Cywinska, A., Ball, S. L. and Dewaard, J. R., Biological identifications through DNA barcodes. Proc. Biol. Sci., 2003, 270, 313-322.

10. Neuenschwander, P., Hammond, W. N. O., Gutierrez, A. P., Cudjoe, A. R., Adjakloe, R., Baumgärtner, J. U. and Regev, U., Impact assessment of the biological control of the cassava mealybug, Phenacoccus manihoti Matile-Ferrero (Hemiptera: Pseudococcidae), by the introduced parasitoid Epidinocarsis lopezi (De Santis) (Hymenoptera: Encyrtidae). Bull. Ent. Res., 1989, 79, 579-594.

11. Nwanze, K. F., Relationships between cassava root yield and infestations by the mealybug, Phenacoccus manihoti. Trop. Pest Manage., 1982, 28, 27-32.

12. Pronam, M'Vuazi, Zaire, Institut National d'Etudes et de Recherches Agricoles/Dept. Agric. (mimeograph). Rapport annuel 1978 , p. 40.

13. Gupta, A., Mohan, M., Sampathkumar, M., Shylesha, A. N., Venkatachalam, S. R. and Bakthavatsalam, N., Cautionary note on the presence of Homalotylus turkmenicus Myartseva (Hymenoptera: Encyrtidae) in the colonies of Phenacoccus manihoti MatileFerrero (Hemiptera: Pseudococcidae) in southern India. J. Biol. Control, 2020, 34(2), 158-160.

14. Wyckhuys, K. A. G., Zhang, W., Prager, S. D., Kramer, D. B., Delaquis, E., Gonzalez, C. E. and van der Werf, W., Biological control of an invasive pest eases pressures on global commodity markets. Environ. Res. Lett., 2018, 13(9), 094005.

15. Wyckhuys, K. A. G. et al., Soil fertility regulates invasive herbivore performance and top-down control in tropical agroecosystems of Southeast Asia. Agric. Ecosyst. Environ., 2017, 249, 38-49.

16. Wyckhuys, K. A. G. et al., Continental-scale suppression of an invasive pest by a host-specific parasitoid underlines both environmental and economic benefits of arthropod biological control. Peer J., 2018, 6, e5796.

17. Cock, M. J. W. et al., The use and exchange of biological control agents for food and agriculture. In Background Study Paper No. 47. Commission on Genetic Resources for Food and Agriculture, FAO, Rome, 2009, p. 88.

ACKNOWLEDGEMENTS. We are grateful to ICAR for funding and Director, ICAR-NBAIR for extending infrastructure facilities. Help in sample collection/data recording/reporting by Director of Horticulture, Bengaluru, Karnataka, Dr P. S. Shanmugam, Programme Coordinator, KVK, Dharmapuri, Tamil Nadu; Dr Gnanasambandam, Assistant Director (Weed Science), CIPMC, Trichy, Tamil Nadu; and Dr M. Janaki, Scientist (Hort.) and Head, AICRP on Tuber Crops, HRS, Peddapuram, East Godavari, Andhra Pradesh are gratefully acknowledged. We also thank the farmers especially, Sh Madeshwaran from Kalkurichi for his field assistance.

Received 7 October 2020; revised accepted 7 November 2020

doi: $10.18520 / \mathrm{cs} / \mathrm{v} 120 / \mathrm{i} 2 / 432-435$ 